\title{
E2F5 wt Allele
}

National Cancer Institute

\section{Source}

National Cancer Institute. E2F5 wt Allele. NCI Thesaurus. Code C162413.

Human E2F5 wild-type allele is located in the vicinity of 8q21.2 and is approximately $40 \mathrm{~kb}$ in length. This allele, which encodes transcription factor E2F5 protein, plays a role in cell proliferation, centriole biogenesis and multiciliate cell differentiation. 